\title{
Hverken grav eller rydning - rituelle røyser fra yngre bronsealder-førromersk jernalder på Sømme i Rogaland
}

\author{
TROND MELING
}

Meling, T. 2020. Neither a grave nor a clearance cairn. Ritual cairns from the Late Bronze Age/Pre-Roman Iron Age at Sømme in Rogaland. AmS-Varia 61, 87-97, Stavanger, ISSN 0332-6306, ISBN 978-82-7760-187-8

This article discusses cairns as ritual constructions during the Late Bronze and Pre-Roman Iron Ages in Southwest Norway. The basis for the discussion are two cairns from Sømme in Sola, Rogaland. It is suggested that the cairns are part of rituals related to settlement expansion and a rapid transformation of the landscape during the period.

Trond Meling, Museum of Archaeology, University of Stavanger, N-4036 STAVANGER. NORWAY.

E-mail: trond.meling@uis.no

Keywords: cairns, rituals, Late Bronze Age, Pre-Roman Iron Age, landscape, transformation

\section{Innledning}

I arkeologien blir røyser i de aller fleste tilfeller enten klassifisert som graver eller som rydningsrøyser. Det visuelle skillet mellom de to kategoriene kan være vanskelig, særlig dersom det er snakk om små og lave røyser (Børsheim, 1999, s. 349). Det er heller ikke uvanlig at begge røystypene ligger side om side (Svanberg, 2000), eller at opprinnelige gravrøyser har blitt omformet og tildekket av rydningsstein på et senere tidspunkt (Børsheim, 1999, s. 350). Selv etter en arkeologisk undersøkelse kan det være problematisk å sette en klar definisjon, spesielt i de tilfellene der antatte gravrøyser er uten funn. Mange røyser uten menneskelevninger eller tradisjonelt gravgods er likevel definert som graver, bl.a. på bakgrunn av oppbygningen, særegne konstruksjonsdetaljer eller beliggenheten i landskapet (bl.a. Dommasnes, 1997, 2001).

Selv om det ikke bør være noen selvfølge at røyser eller steinlegginger defineres som graver eller rydninger, er det sjelden at de tolkes som uttrykk for noe annet (Kaliff, 1997, s. 69, 1998, s. 179, 2004, s. 29-30, Gansum, 2002, s. 253). Anders Kaliff (1997, s. 68-70, 1998) har påpekt at røysene viser et stort mangfold $i$ yngre bronsealder og førromersk jernalder, og har foreslått at enkelte kan ha fungert som altere. Vivian
Wangen $(1998,2009)$ har også studert variasjonen blant røyser og ulike steinlegginger i denne perioden. Hennes utgangspunkt har vært gravfeltet Gunnarstorp i Østfold, og hun argumenterer for at røysene og steinleggingene uten menneskelevninger ikke nødvendigvis er graver. Disse anleggene skal heller sees på som et resultat av rituelle aktiviteter der selve arbeidet med konstruksjonen var den viktigste handlingen (Wangen, 1998, s. 167, 2009, s. 136-137). Både Kaliff og Wangen understreker at de mange variasjonene innenfor gravfeltene viser at de må ha vært noe mer enn bare et sted der de døde ble stedt til hvile. Feltene skal heller oppfattes som hellige steder eller kultplasser der en har utført en rekke ritualer. Foruten å gravlegge de døde, har feltene trolig vært viktige for å opprettholde mellommenneskelige relasjoner og for å komme i kontakt med høyere makter i en videre sammenheng (Wangen, 2009, s. 137).

I denne artikkelen følger jeg langt på vei Kaliff og Wangens ideer om gravfeltet og røysen som noe mer enn et sted for begravelser, og jeg vil vise at røysen som anlegg og fenomen kan innbefatte et bredt spekter av ritualer. Utgangspunktet for diskusjonen er to røyser på gården Sømme i Sola kommune som ble undersøkt i 2014 ${ }^{1}$ (Fig. 1). Begge kan dateres til yngre bronsealder 
Fig. I. De to røysene på Sømme lå på en flate mellom Hafrsfjord og Solavika. I nærområdet er det påvist en rekke bosetningsspor fra bronsealder og førromersk jernalder, og denne delen av Nord-Jæren fremstår som et av de mest funnrike områdene i Rogaland i denne perioden. Illustrasjon: Trond Meling/Theo Gil Bell.

Fig. I. The two cairns at Sømme were located between Hafrsfjord and Solavika in the northern part of Jæren, in Southwest Norway. There are many finds from the Bronze Age and Pre-Roman Iron Age in the area, and it seems to have been densely populated during this period. Illustration: Trond Meling/Theo Gil Bell.

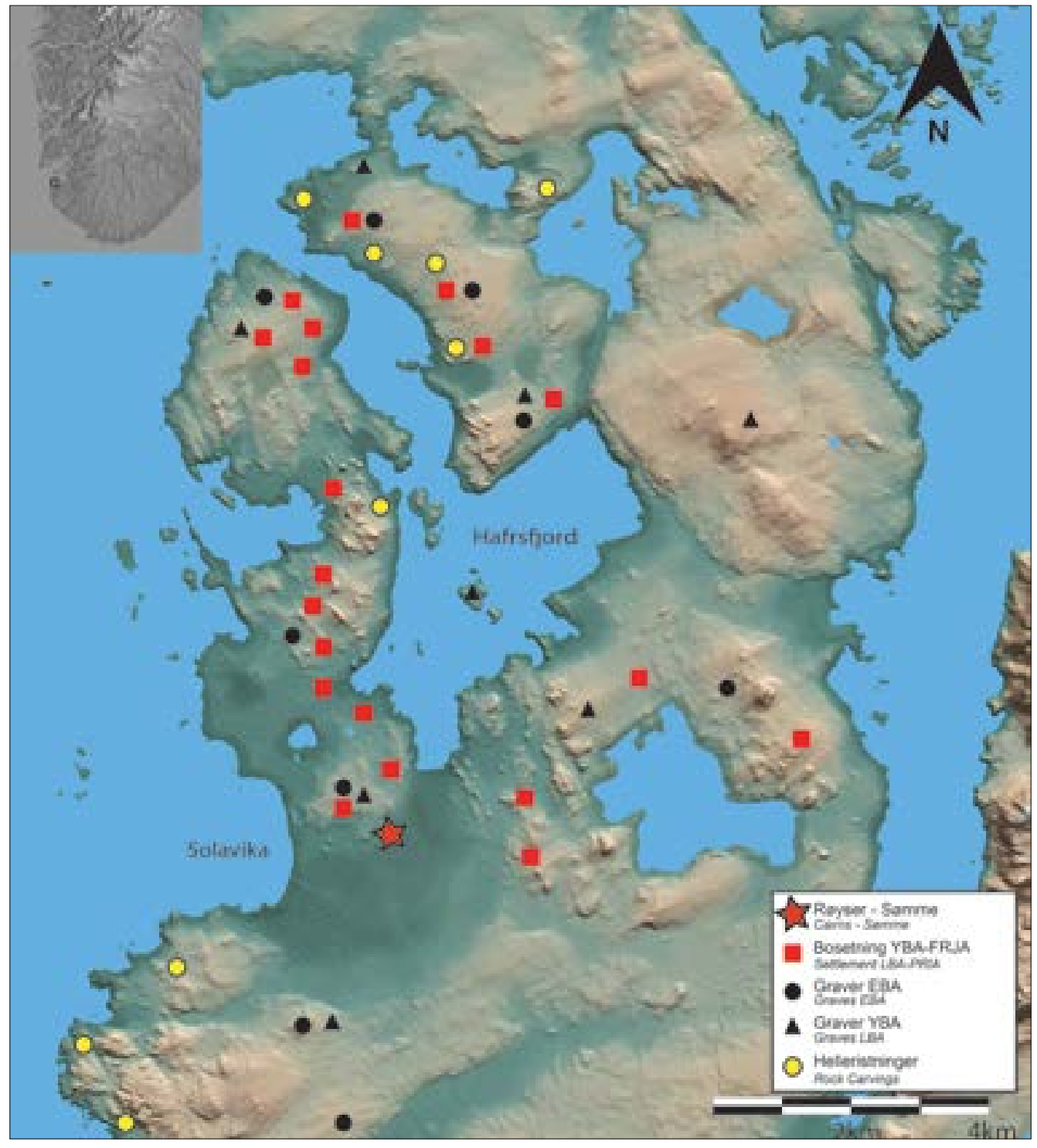

en lignende situasjon (Myhre, 1981), og fra området er det bl.a. en hel del laus-/depotfunn fra sein-neolitikum og bronsealder, mange rike gravfunn fra bronsealder og flere helleristningslokaliteter (Fig. 1). De siste årene er det også registrert og undersøkt omfattende bosetningsspor rundt Hafrsfjord, særlig fra sein-neolitikum og framover mot Kr.f. (bl.a. Tansøy, 2001; Bertheussen, 2008; Bjørlo, 2011; Eilertsen, 2013, 2016; Dahl, 2014; Fyllingen, 2015; Meling, 2017).

De to røysene, som lå på en flate (ca. 8 moh.) mellom Hafrsfjord og Solavika, ble bygget sentralt i dette jordbrukslandskapet. Før utgravingen var hele flaten dekket av 0,5-1 m tykk torv og 1-2 m med flygesand (Fig. 2). Dette har skapt svært gode bevaringsforhold, særlig for bein (Denham, 2016; Meling, 2016). Tett ved røysene fantes det fire boplasser datert til overgangen mellom eldre og yngre steinalder (Fig. 3), og på disse ble det samlet inn ca. 50000 beinfragmenter (Meling, 2016). Begge røysene var anlagt i den nedre delen av 
torvlaget som dekket flaten, og lå ca. $20 \mathrm{~m}$ fra hverandre (Fig. 2).

Det ble ikke påvist spor etter hus eller andre konstruksjoner som indikerer at det har vært en jordbruksbosetning på flaten. På to av de nærliggende steinalderboplassene fantes det imidlertid tre enkeltliggende kokegroper som er datert til yngre bronsealder (Fig. 3). I den ene av disse lå det en hel del ubrente hjortebein og -tenner, men en ${ }^{14} \mathrm{C}$-datering viser at disse er fra slutten av eldre steinalder (Tabell 1), og at de må ha blitt inkorporert i massene da gropen ble fylt igjen. Det var ingen andre funn, hverken i eller rundt gropene, som kan si noe om funksjonen, men sannsynligvis vitner de om kortvarige opphold på stedet. Naturvitenskapelige undersøkelser viser at området ble benyttet til beite i slutten av sein-neolitikum og gjennom store deler av bronsealder (Prøsch-Danielsen, 1993), så det er mulig at kokegropene skal relateres til dette.

Ved overgangen til førromersk jernalder ble deler av flaten også dyrket (Prøsch-Danielsen, 1993). Åkrene har ligget 60-80 m fra røysene og i samme område som kokegropene. Dyrkingen ser ut til å ha vært relativt kortvarig, og i første halvdel av førromersk jernalder ble hele området dekket av flygesand (Prøsch-Danielsen, 1993; Selsing \& Mejdahl, 1994; Prøsch-Danielsen \& Selsing, 2009). Sandflukten var forholdsvis omfattende (Fig. 2), og det er påvist tilsvarende tykke flygesandslag

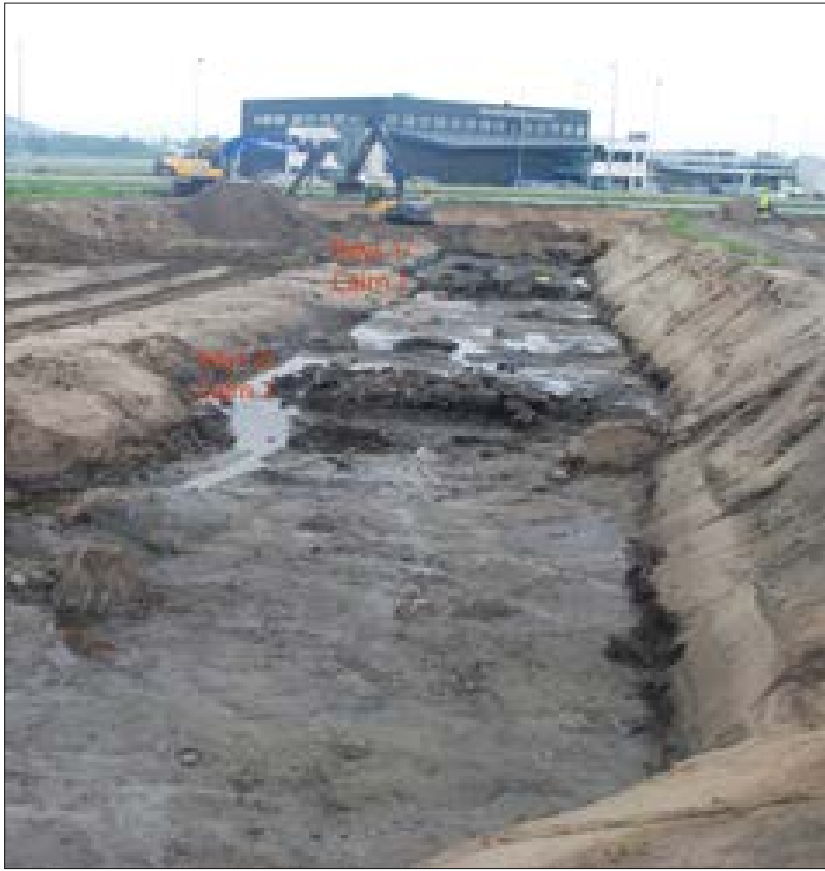

Fig. 2. De to røysene var dekket av tykke lag med torv og flygesand. Nærmest ligger røys 2, mens deler av røys I kan skimtes i bakgrunnen. Sett mot $S \varnothing$. Foto: Arkeologisk museum, UiS. Fig. 2. Both cairns were sealed below massive layers of peat and aeolian sand. Cairn 2 is in the foreground, while parts of cairn I is visible in the background. Photo: Museum of Archaeology, University of Stavanger.

flere steder mellom Hafrsfjord og Solavika (Selsing \& Mejdahl, 1994; Prøsch-Danielsen \& Selsing, 2009;

Tabell I. ${ }^{14} \mathrm{C}$-dateringer fra kokegroper og røys I på Sømme

Table I. ${ }^{14} \mathrm{C}$-dates from cooking pits and cairn I at Sømme

\begin{tabular}{|c|c|c|c|c|c|}
\hline $\begin{array}{l}\text { Kontekst } \\
\text { Context }\end{array}$ & $\begin{array}{l}\text { Datert materiale } \\
\text { Dated material }\end{array}$ & $\begin{array}{l}\text { Lab.-Id. } \\
\text { Lab.-Id. }\end{array}$ & $\begin{array}{l}\text { Datering før } \\
\text { nåtid (BP) } \\
\text { Uncal. } \\
{ }^{14} \text { C-years BP }\end{array}$ & $\begin{array}{l}\text { Kalibrert alder }(\mathbf{6 8}, \mathbf{3} \%) \\
\text { Calibrated age } \mathrm{BC} \boldsymbol{\sigma}\end{array}$ & $\begin{array}{l}\text { Kalibrert alder } \\
(\mathbf{9 4 , 4 \% )} \\
\text { Calibrated age BC } 2 \sigma\end{array}$ \\
\hline $\begin{array}{l}\text { Steinlegging } \mathrm{Ia} / \\
\text { Stone setting } \mathrm{la}\end{array}$ & $\begin{array}{l}\text { Kjeve fra hjort } \\
\text { (Cervus elaphus)/Red deer } \\
\text { (Cervus elaphus) mandible }\end{array}$ & UBA-33482 & $2171 \pm 31$ & $352-296 / 229-220 / 212-176$ f.Kr./BC & $\begin{array}{l}360-157 / 133-117 \\
\text { f.Kr./BC }\end{array}$ \\
\hline $\begin{array}{l}\text { Steinlegging } \mathrm{la} / \\
\text { Stone setting } \mathrm{la}\end{array}$ & $\begin{array}{l}\text { Gjenstand i ask (Fraxinus } \\
\text { excelsior)/Object made of ash } \\
\text { (Fraxinus excelsior) }\end{array}$ & UBA-32495 & $2516 \pm 38$ & $780-745 / 686-665 / 643-552$ f.Kr./BC & $\begin{array}{l}796-536 / 527-521 \\
\text { f.Kr./BC }\end{array}$ \\
\hline $\begin{array}{l}\text { Steinlegging } \mathrm{Ib} / \\
\text { Stone setting } \mathrm{Ib}\end{array}$ & Løvtre/deciduous trees & UBA-28334 & $5070 \pm 31$ & 3944-39/4/3878-3804 f.Kr./BC & 3956-3795 f.Kr./BC \\
\hline $\begin{array}{l}\text { Steinlegging } \mathrm{Ib} / \\
\text { Stone setting } \mathrm{lb}\end{array}$ & $\begin{array}{l}\text { Gevir fra hjort (Cervus } \\
\text { elaphus)/Red deer (Cervus } \\
\text { elaphus) antlers }\end{array}$ & UBA-33478 & $2560 \pm 37$ & $\begin{array}{l}802-752 / 682-669 / 632-630 / \\
612-592 \text { f.Kr./BC }\end{array}$ & $\begin{array}{l}807-735 / 688-663 / \\
647-547 \text { f.Kr./BC }\end{array}$ \\
\hline $\begin{array}{l}\text { Kokegrop } 6375 / \\
\text { Cooking pit } 6375\end{array}$ & $\begin{array}{l}\text { Hassel (Corylus) } \\
\text { hazel (Corylus) }\end{array}$ & UBA-28330 & $2712 \pm 26$ & $894-865 / 856-827$ f.Kr./BC & $906-812$ f.Kr./BC \\
\hline $\begin{array}{l}\text { Kokegrop } 6400 / \\
\text { Cooking pit } 6400\end{array}$ & $\begin{array}{l}\text { Hassel (Corylus) } \\
\text { hazel (Corylus) }\end{array}$ & UBA-28329 & $2855 \pm 29$ & 1055-974/956-94I f.Kr./BC & $1113-930$ f.Kr./BC \\
\hline $\begin{array}{l}\text { Kokegrop S-5/ } \\
\text { Cooking pit S-5 }\end{array}$ & $\begin{array}{l}\text { Bjørk/Or/Hassel (Betula/ } \\
\text { Alnus/Corylus)/Birch/alder/ } \\
\text { hazel (Betula/Alnus/Corylus) }\end{array}$ & UBA-28333 & $2545 \pm 26$ & $795-754 / 68 I-670 / 609-594$ f.Kr./BC & $\begin{array}{l}799-746 / 685-666 / \\
643-552 \text { f.Kr./BC }\end{array}$ \\
\hline $\begin{array}{l}\text { Kokegrop S-5/ } \\
\text { Cooking pit S-5 }\end{array}$ & $\begin{array}{l}\text { Hjortetann (Cervus elaphus) } \\
\text { Red deer (Cervus elaphus) tooth }\end{array}$ & UBA-34249 & $5317 \pm 37$ & $\begin{array}{l}4232-4220 / 4212-4190 / \\
4 I 80-4 I 52 / 4134-4060 \text { f.Kr./BC }\end{array}$ & $\begin{array}{l}4308-4305 / \\
4260-4042 \text { f.Kr./BC }\end{array}$ \\
\hline
\end{tabular}


Fig. 3. Tett ved røysene fantes det fire boplasser fra overgangen mellom eldre og yngre steinalder og tre kokegroper fra yngre bronsealder. Illustrasjon: Trond Meling. Fig. 3. Adjacent to the cairns were three Late Mesolithicl Early Neolithic dwelling sites and three cooking pits dated to the Late Bronze Age. Illustration: Trond Meling.

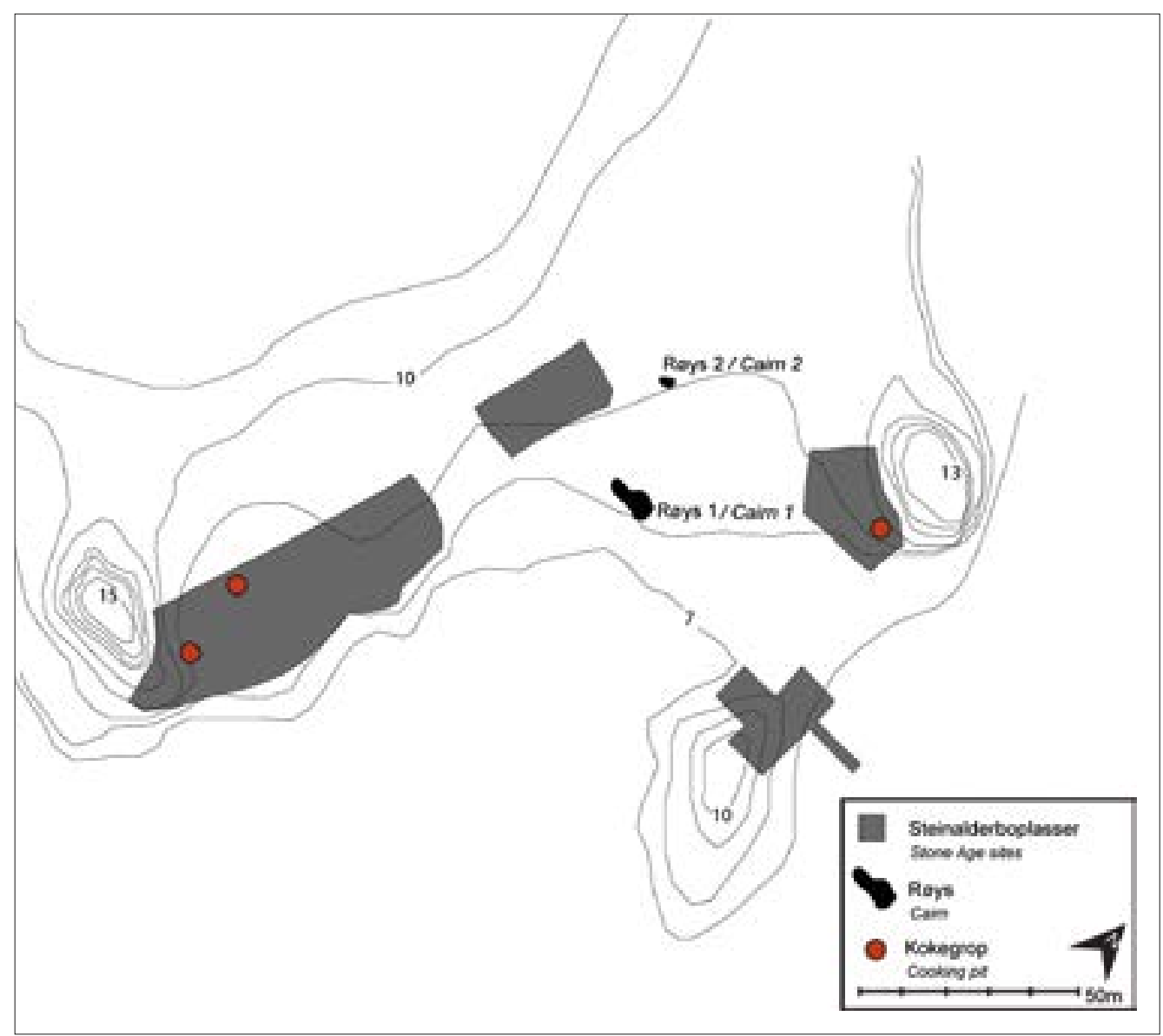

Aanderaa, 2015; Meling, 2017). Denne delen av NordJæren er svært utsatt for sandflukt på grunn av det flate kystnære landskapet og mange strandsandavsetninger. Det er imidlertid menneskelig påvirkning som har vært hovedårsaken til den betydelige sandflukten i førromersk jernalder. Kombinasjonen av langvarig bosetningsekspansjon, omfattende avskoging og økt beitepress førte til at mange av de naturlige vegetasjonsbarrierene forsvant, og at erosjonen økte (Selsing \& Mejdahl, 1994; Prøsch-Danielsen \& Selsing, 2009).

Selv om det ikke er påvist bosetning på flaten har røysene blitt anlagt i et kulturlandskap og i nær relasjon til den samtidige gårdsbosetningen. De nærmeste gårdene lå på et høydedrag ca. $500 \mathrm{~m}$ unna (Fig. 1), og i disse områdene har det vært mer eller mindre kontinuerlig jordbruksbosetning fra sein-neolitikum til midten av førromersk jernalder (Tansøy, 2001; Meling, 2017). Sannsynligvis var flaten med de to røysene en av flere ryddete områder som lå i ytterkanten av boplassområdene, og som vekselvis ble benyttet til beite og dyrking.

\section{Beskrivelse av Røys 1}

Etter avdekkingen fremstod røys $1^{2}$ som langoval med en noe ujevn kurvatur. Den var ca. $11 \mathrm{~m}$ lang og rundt $4 \mathrm{~m}$ på det bredeste. Etter hvert som de øverste steinene ble fjernet, viste det seg at disse skjulte to steinlegginger $^{3}$ (steinlegging 1a og steinlegging $1 \mathrm{~b}$ ) som lå tett inntil hverandre (Fig. 4).

Steinlegging la utgjorde den vestlige delen av røysen. Den hadde en rundoval form (ca. $5 \mathrm{~m}$ i tverrmål) med forholdsvis store steiner langs ytterkanten. I sentrum og på bunnen av steinleggingen fantes det en forhøyning som var bygget opp av undergrunnsmasser og dekket av relativt flate steiner (Fig. 4). Forhøyningen var anlagt inntil en forholdsvis stor jordfast stein med en avrundet form. Rundt deler av forhøyningen fantes det også en tydelig forsenkning i undergrunnen. Mellom de flate steinene som dekket forhøyningen lå deler av en hjortekjeve som er ${ }^{14} \mathrm{C}$-datert til første halvdel av førromersk jernalder (Tabell 1). I ulike nivåer i den nordlige og vestlige delen av steinleggingen fantes det en samling skjell, to malesteiner og en gjenstand i tre. Skjellene, som hovedsakelig består av østers (Ostrea edulis), samt enkelte blåskjell (Mytilus edulis) og strandsnegler (Littorina littorea), lå samlet på en av steinene i kanten av steinleggingen. Gjenstanden i tre lå også i ytterkanten, innkapslet i torv. Den er ca. $20 \mathrm{~cm}$ lang og laget av en $4 \mathrm{~cm}$ tykk gren eller stamme av ask (Fraxinus excelsior). Gjenstanden er svært forseggjort med en regelmessig, rektangulær uthuling og tydelige 


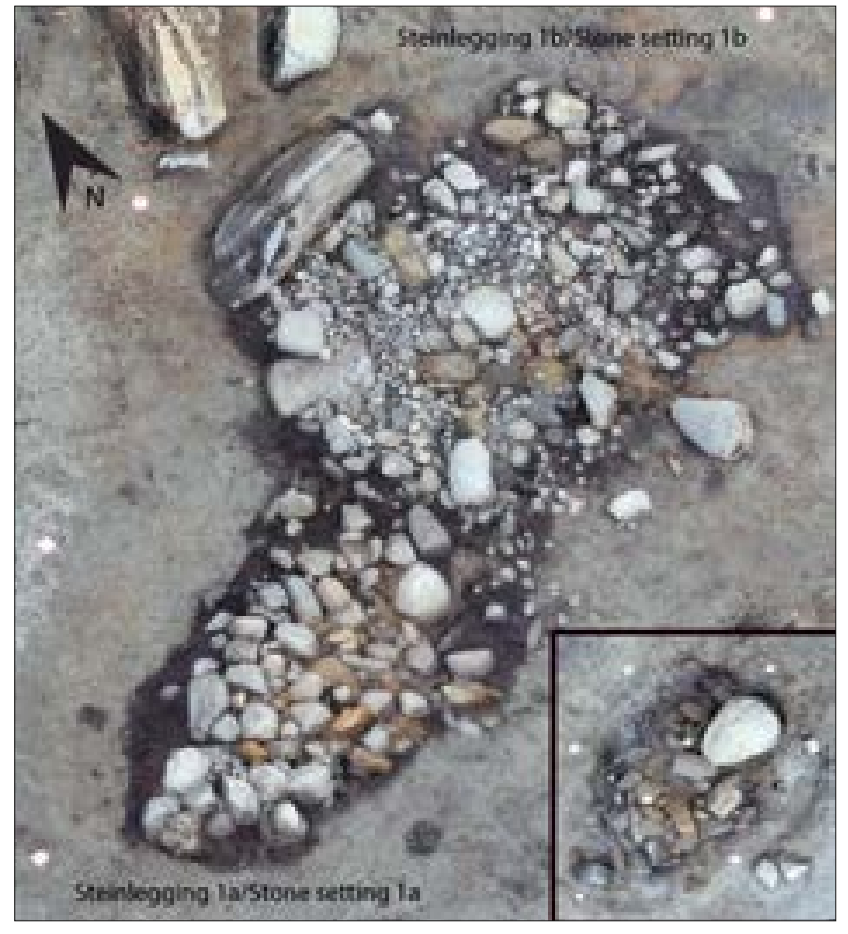

Fig. 4. Etter at de øverste lagene med stein ble fjernet fra den største røysen kom det fram to steinlegginger. Steinlegging la ses i nedre billedkant, mens steinlegging Ib ses i øvre del av bildet. I det innfelte fotografiet er forhøyningen av undergrunnsmasser som fantes på bunnen og i sentrum av steinlegging la avbildet. Sett mot NØ. Fotomosaikk: Sarita Louzolo/ Arkeologisk museum, UiS

Fig. 4. The largest cairn was made of two adjacent stone settings, which became visible when the top layer of stones was removed. Stone setting $l a$ in the lower part of the picture, and stone setting $l b$ in the upper part. The inset photo shows an elevation of silt and clay, found in the lower and central part of stone setting la. Photo towards northeast. Photo mosaic: Sarita Louzolo/ Museum of Archaeology, University of Stavanger

furer i begge endene (Fig. 5). Funksjonen er ikke kjent, men den er ${ }^{14} \mathrm{C}$-datert til slutten av yngre bronsealder (Tabell 1). De to runde malesteinene ble funnet blant de andre steinene i den vestlige delen av steinleggingen. Begge har en diameter på rundt $12 \mathrm{~cm}$ og tydelige slipeflater på den ene siden.

Steinleggingen $1 \mathrm{~b}$ var ca. 6,0 x 4,5 m stor og mer avflatet i formen enn 1a. Den var anlagt tett opp til to store jordfaste steiner som dannet en avgrensning mot nord og nordvest (Fig. 4). På bunnen lå det flere flate steiner som dannet en noe uregelmessig plattformlignende formasjon (Fig. 6). I den vestlige delen av plattformen lå de flate steinene direkte på undergrunnen, mens det fantes opp mot $20 \mathrm{~cm}$ tykk torv under steinene i den sentrale og østlige delen. Torven i den sentrale delen var trekullholdig ned mot bunnen, og dette nivået er ${ }^{14} \mathrm{C}$-datert til tidlig-neolitikum (Tabell 1). I den østlige kanten av plattformen, og delvis mellom to steiner, ble det funnet et hjortegevir som er ${ }^{14} \mathrm{C}$-datert til yngre bronsealder (Tabell 1).
Dateringene indikerer at røys 1 er bygget i perioden yngre bronsealder-førromersk jernalder, og at steinlegging $1 \mathrm{~b}$ er minst 200 år eldre enn 1a (Tabell 1). Steinkappen som dekket de to steinleggingene ble trolig anlagt samtidig med eller kort tid etter oppbygningen av 1a. Siden tregjenstanden har en sammenfallende datering med hjortegeviret, kan vi imidlertid ikke utelukke at begge steinleggingene er bygget $i$ yngre bronsealder, og at hjortekjeven og steinkappen er kommet til i førromersk jernalder. Det er vanskelig å «lese» hele hendelsesforløpet i oppbygningen, men uansett viser både dateringene og de mange konstruksjonsdetaljene at røysen ble til gjennom en serie med handlinger over tid.

\section{Beskrivelse av Roys 2}

Denne røysen hadde en rundoval form og var ca. 3,5 m lang og 1,5 m bred. Den var forholdsvis lav og bygget opp av to lag med stein av varierende størrelse (Fig. 2). Det fantes ingen avgrensede lag eller konstruksjonsspor i eller under røysen, men steinene så ut til å være sortert siden de største lå langs ytterkanten og i den sørlige halvdelen. Det nedre laget med stein dannet en relativt plan flate. Under røysen var det $15-20 \mathrm{~cm}$ tykk torv som trolig representerer den tids markoverflate.

Mellom steinene i bunnen av røysen, og delvis ned i torven, ble det funnet to keramikkskår og et $16 \mathrm{~cm}$ langt, kjegleformet trestykke med avrundede ender. På overflaten av trestykket er det flere små fordypninger og hakk som kan være verktøyspor. I tillegg er deler av overflaten brent. De to keramikkskårene har ingen dekor, men begge er kvartsmagret og har en lysebrun farge, så sannsynligvis stammer de fra samme kar.

Det foreligger ingen ${ }^{14} \mathrm{C}$-dateringer fra røysen, men en rekke dateringer fra den overliggende torven og flygesanden viser at den må være eldre enn midten av førromersk jernalder (jf. Prøsch-Danielsen, 1993; Selsing \& Mejdahl, 1994; Prøsch-Danielsen \& Selsing,

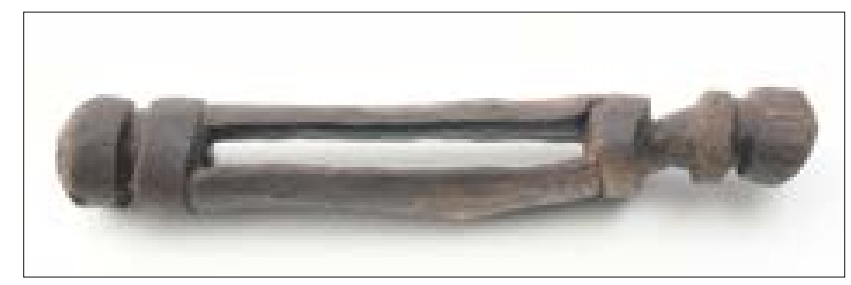

Fig. 5. I steinlegging la ble det funnet en forseggjort gjenstand i asketre (Fraxinus excelsior). Den er ca. $20 \mathrm{~cm}$ lang med en rektangulær uthuling og markante furer i hver ende. Funksjonen er ukjent. Foto: Terje Tveit, Arkeologisk museum, UiS Fig. 5. A delicately crafted, $20 \mathrm{~cm}$ long object made of ash (Fraxinus excelsior), was found in stone setting la. The object's function is unknown. Photo: Terje Tveit, Museum of Archaeology, University of Stavanger 
Fig. 6. På bunnen av steinlegging $\mathrm{Ib}$ fantes det flere flate steiner som dannet en plattformlignende formasjon. Sett mot $\varnothing$. Foto: Arkeologisk museum, UiS.

Fig. 6. Stone slab platform at the bottom of stone setting Ib. Photo towards east. Photo: Museum of Archaeology, University of Stavanger.

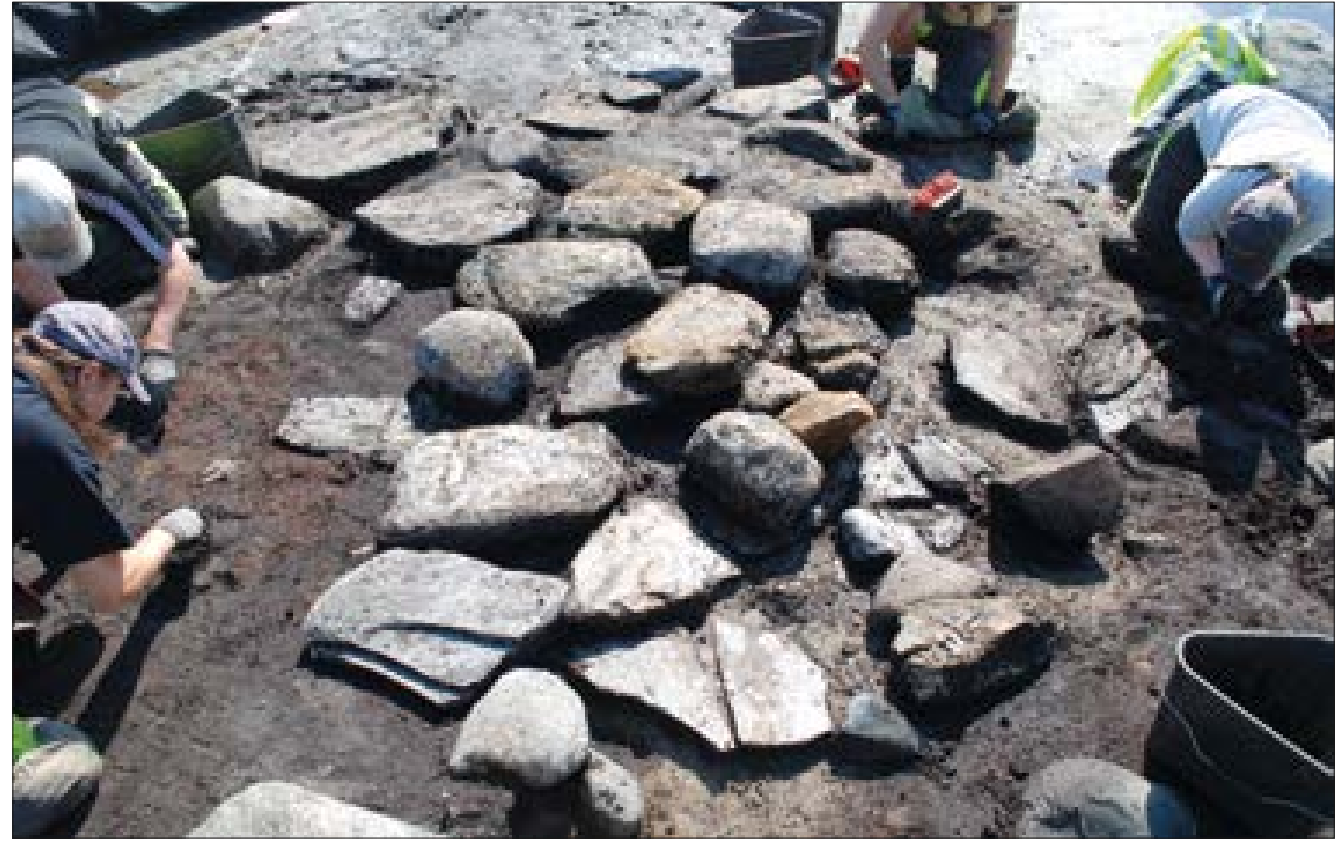

2009). Tykkelsen på torvlaget under røysen og nærheten til røys 1 sannsynliggjør at den er anlagt i yngre bronsealder eller førromersk jernalder. En slik datering stemmer også forholdsvis bra med de to keramikkskårene, selv om disse ikke kan tidfestes nøyaktig ut fra typologiske trekk.

\section{Røysene på Sømme sammenlignet med graver fra bronsealder- førromersk jernalder}

Det er lite trolig at de to røysene representerer en rydding av flaten, selv om deler av den har blitt dyrket $\mathrm{i}$ overgangen til førromersk jernalder. Med unntak av en del store, jordfaste blokker var det lite stein i området, så behovet for å rydde åkrene har trolig vært svært begrenset. Det er heller ingenting som tilsier at røysene eller funnmaterialet er spor etter rydding eller andre dagligdagse aktiviteter relatert til en bebyggelse på stedet i yngre bronsealder og førromersk jernalder. Det ble riktignok funnet mye hjortebein på steinalder-boplassene (Denham, 2016), men samtlige av disse ser ut til å være fra tiden rundt 4000 f.Kr. Alle objektene som fantes i røysene, har derfor trolig blitt tilført området i den hensikt at de skulle deponeres i røysene.

Ut fra oppbygningen og funnmaterialet ville det kanskje være nærliggende å tolke røysene som gravminner. De gode bevaringsforholdene gjør imidlertid en slik tolkning problematisk. Dersom det var lagt ned menneskelevninger i røysene, ville beinene etter all sannsynlighet vært bevart, uavhengig av om den døde var kremert eller ikke. Både funnmaterialet og de mange konstruksjonsdetaljene har imidlertid flere likheter med gravminner fra bronsealder og førromersk jernalder.

\section{Oppbygningen av roysene}

I begge røysene fra Sømme fantes det partier med forholdsvis flate steiner. Disse var mest tydelige i røys 1, særlig på bunnen av steinlegging $1 \mathrm{~b}$ og over den kuppelformede forhøyningen i 1a, men også i røys 2 fantes det et relativt plant parti på bunnen. Lignende oppbygninger av flate heller har en påvist i flere av røysene innenfor et stort gravfelt på Vereide i Gloppen, Sogn og Fjordane (Dommasnes, 1997, 2001). Størrelsen til disse hellelegningene varierer, men samtlige lå ned mot bunnen av røysene (Dommasnes, 1997, s. 111, 2001, s. 99). Dette fenomenet forekommer også flere steder i Sverige hvor en har avdekket alt fra enkeltliggende til større konsentrasjoner av flate steiner i bunnen av gravrøyser fra bronsealder (bl.a. Feldt, 2005, s. 75, 144; Munkenberg, 2010, s. 246). Noen av steinleggingene innenfor det tidligere nevnte gravfeltet på Gunnarstorp i Østfold hadde også en eller to heller i sentrum av konstruksjonen (Wangen, 2009, s. 60).

På Vereide hadde flere av røysene, i likhet med steinlegging 1a på Sømme, en tydelig forhøyning under selve røysen. Disse fremstod nærmest som en sokkel og var bygget opp av undergrunnsmasser (Dommasnes, 1997, s. 116-119, 2001, s. 99). Rundt forhøyningene fantes det i flere tilfeller en tydelig forsenkning langs ytterkanten, og en antar at disse er et biprodukt etter de oppspadde massene som er brukt for å konstruere forhøyningene (Dommasnes, 1997, s. 119). Det ble ikke påvist flate steiner over forhøyningene på Vereide, slik 
som på Sømme, men i flere tilfeller fantes det et tydelig skille til resten av røysen ved at det lå finkornet lys sand mellom sokkelen og steindekket (Dommasnes, 1997, s. 121).

Jordfaste steiner er også et trekk ved flere graver fra denne perioden (Hinsch, 1953, s. 55-56; Pilø, 1989, s. 34; Dommasnes, 1997). Gravene kan være anlagt inntil en stein, uten noen annen form for synlig markering, eller steinene kan utgjøre en del av haugen/røysen. I en del tilfeller er haugen bygget opp rundt en jordfast stein, slik at denne danner sentrum i gravanlegget (bl.a. Lund, 1939; Dommasnes, 1997, s. 109), men det er også eksempler på at jordfaste steiner har inngått i den ytre avgrensningen til gravminnet (bl.a. Lillehammer, 1976; Wangen, 2009, s. 61). Noen ganger har en også markert ytterkanten med store steiner reist på høykant (Myhre, 1971, 1981, s. 109; Wangen, 2009, s. 61). På Sømme er flere av disse elementene til stede ved at en forholdsvis høy og markant jordfast stein inngikk som en del av sentrumsmarkeringen i steinleggingen 1a (Fig. 4), mens to store jordfaste steiner dannet en ytre avgrensning til steinleggingen $1 \mathrm{~b}$ (Fig. 4).

\section{Funnmaterialet fra røysene}

Flere av funnene fra røysene på Sømme har klare paralleller til gravfunn fra bronsealder og førromersk jernalder. Dette gjelder særlig keramikken, men også skjell, malesteiner og dyrebein forekommer i graver fra denne perioden.

Leirkar opptrer ofte som beholdere for brente bein Dette gjelder særlig i førromerske graver (Hinsch, 1953; Pilø, 1989, s. 32; Nybruget \& Martens, 1997, s. 86; Rødsrud, 2004, s. 279, 2008, s. 398-399), men også i bronsealder er det en klar sammenheng mellom kremasjon og keramikk (Melheim, 2006, s. 97). Ofte er det kun påvist små samlinger eller et fåtall keramikkskår (Rødsrud, 2012, s. 58), slik tilfellet er på Sømme. Et eksempel på dette er Gunnarstorp hvor det kun fantes rester av knuste leirkar i over halvparten av gravene med keramikk (Wangen, 2009, s. 78). Enkelte ganger kan fragmenteringen trolig forklares ut fra dårlige bevaringsforhold, men i majoriteten av tilfellene skyldes de få skårene at kun deler av karene er lagt ned i gravene (Dommasnes, 2001, s. 106; Bäck \& Gansum, 2004; Wangen, 2009, s. 78; Rødsrud, 2012, s. 58).

I flere graver fra bronsealder langs kysten mellom Agder og Trøndelag, er det funnet skjell og sneglehus (Myhre, 2004; Grønnesby, 2009; Anfinsen, 2016). Albueskjell (Patella vulgata) og strandsnegl (Littorina littorea) dominerer, men også andre typer forekommer, bl.a.blåskjell (Mytilus edulis), hjerteskjell (Cerastoderma edule) og østers (Ostrea edulis) (Anfinsen, 2016, s. 21). I de fleste tilfellene er skjellene lagt ned sammen med annet gravgods, enten som enkeltskjell eller som større samlinger. Det er imidlertid også eksempler på at skjellene er deponert utenfor selve gravgjemmet, bl.a. i en haug fra eldre bronsealder på Bore i Klepp, Rogaland (Lund, 1934, s. 62).

Male-/kvernsteiner forekommer også i en del graver, særlig i Sverige (bl.a. Kaliff, 1992, s. 99, 1997, s. 88-90; Stålbom, 1997, s. 29). I Norge er det påvist en konsentrasjon av graver med malesteiner i området rundt Lista i Agder (Bjørn, 1927; Melheim, 2016, s. 34). Flertallet av disse kan dateres til slutten av yngre steinalder og eldre bronsealder. I likhet med situasjonen på Sømme, er mange av steinene funnet i røys-/haugfyllen (Melheim, 2016, s. 34).

Det er funnet dyrebein i en del kremasjonsgraver fra bronsealder og førromersk jernalder, og i det svenske materialet, særlig fra bronsealder, forekommer bein fra ville arter forholdsvis ofte (Axelsson, 2005; Vretemark, 2013). Materialet fra Norge er kun sporadisk analysert, men på Gunnarstorp fantes det dyrebein i 12 graver (Wangen, 2009, s. 72). Bare noen få av disse kunne artsbestemmes, men både storfe, mindre pattedyr og fugl er identifisert (Wangen, 2009, s. 73). I en av gravene fra Gunnarstorp ser det ut til å være kun dyrebein (Wangen, 2009, s. 132). En parallell til dette ser en i noen graver fra eldre bronsealder i Steinkjer i Nord-Trøndelag, hvor det er påvist langt flere dyrebein enn menneskebein (Grønnesby, 2009, s. 72). Det er funnet hjortebein i enkelte graver fra yngre bronsealder i Sverige, bl.a. i en stor gravhaug fra Skultorp i Västergötland (Axelsson, 2005; Vretemark, 2013). Her lå det ubrente hjortebein i et brannlag på bunnen av haugen, samt ubrente hjortegevir i to groper rundt haugen (Vretemark, 2013, s. 212).

\section{Røysene på Sømme og bosetningsekspansjonen i bronsealder-førromersk jernalder}

En konsekvens av den omfattende bosetningsekspansjonen på Nord-Jæren fra slutten av yngre steinalder og fremover, var at skogs- og utmarksområder ble transformert til gårder, åkrer og beitemarker i et forholdsvis raskt tempo. I yngre bronsealder og førromersk jernalder er denne utviklingen særlig markant, og bosetningen i perioden blir gjerne karakterisert som flytende siden heus og gårdene stadig måtte reetableres når nye generasjoner overtok (Herschend, 2009, s. 141). På en av gårdene som lå nærmest de to røysene ser en dette tydelig, og her er det påvist minst seks generasjoner 
med hus datert til slutten av yngre bronsealder og første halvdel av førromersk jernalder (Meling, 2017).

Flere av funnene fra de to røysene kan også relateres til ulike transformasjoner. Keramikk kan bl.a. betraktes som et sluttprodukt der utgangspunktet har vært leire og kvarts som gjennom forskjellige stadier er bearbeidet, formet og brent (Fredriksen, 2005, 2006). Ved byggingen av røys 2 har keramikken gått igjennom nok en transformasjon ved at karet ble knust og utvalgte deler lagt ned mellom steinene (jf. Wangen, 2009, s. 35). Malesteiner er også en gjenstandsgruppe som forbindes med transformasjoner. De forekommer ofte på boplasser, og i mange tilfeller er de rituelt deponert i bygninger og groper (Stålbom, 1997; Holmberg, 1998; Carlie, 2004). Steinene blir gjerne koblet til fruktbarhet og reproduksjon, og ved å male korn og frø ble maten transformert fra natur til kultur (Stålbom, 1997, s. 29). Anders Kaliff (1992, s. 100, 1997, s. 88) har foreslått at malesteiner funnet i kremasjonsgraver ble brukt til å knuse beinene, og gjennom denne handlingen ble kroppen brutt ned og sjelen frigjort. Skjell og strandsnegler kan også assosieres med sjelen og den dødes reise til det hinsidige. Mange av de jordbygde gravhaugene fra bronsealder har en kjernerøys. Denne røysen er tolket som et symbol på strandsonen, mens skjellene relateres til vann og hav (Myhre, 2004, s. 218). Metaforisk har den døde, via de ulike elementene i gravminnet, vært igjennom en transformasjon og passert sentrale deler av landskapet (jord, strandsone og hav) hvor haugene ble bygget (Myhre, 2004, s. 218). Hjorten kan sees på en lignende måte. Dette dyret holder først og fremst til i løvskogene, men trives også i det åpne menneskeskapte jordbrukslandskapet (Rosvold, Andersen, Linell \& Hufthammer, 2013, s. 1148). Denne egenskapen gjør at hjorten kan oppholde seg i ulike soner og krysse barrierene som fantes mellom det domestiserte landskapet og utmarka.

Oppbygningen av røys 1 kan også sees på som et uttrykk for transformasjoner og endringer over tid. Røysen har blitt til over en periode på minst 200 år, og de ulike elementene er sannsynligvis tilført anlegget i faser gjennom hele dette tidsrommet. I likhet med flere helleristninger og graver fra bronsealder er det fristende å tolke de mange nedleggelsene og konstruksjonsdetaljene som en narrativ fortelling (jf. Myhre, 2004, s. 213; Melheim, 2006, s. 122). Det er vanskelig å tyde denne fortellingen, men hjorten ser ut til å ha spilt en sentral rolle siden dyret er representert både i den eldste og yngste fasen. I begge fasene er deler av hodet deponert. Dette er et trekk vi også ser i flere husoffer, og sannsynligvis skyldes det forestillinger om at dyrets sjel og livskraft lå i hodet (Carlie, 2004, s. 192). De flate steinene er også et gjennomgående tema i røysen. I graver fra bronsealder er slike steiner ofte benyttet for å skape rom og avgrensninger i kjernen av gravminnet, noe som igjen har vært viktige element i forhold til de transformasjonene den døde gikk igjennom (Myhre, 2004, s. 221). Det er mulig at lignende forestillinger ligger bak plasseringen av de flate steinene i røysen på Sømme. I steinlegging $1 b$, som utgjør den eldste delen av anlegget, lå steinene på bunnen, mens de dekket forhøyningen i den yngre 1a. Disse kronologiske og formmessige forskjellene fremstår som ulike narrativ og gir assosiasjoner til begynnelsen og slutten av et hendelsesforløp/transformasjon. Det siste og yngste elementet i røysen er steinkappen som skjulte de to steinleggingene. Denne skal trolig oppfattes som en forsegling av hele anlegget og som et uttrykk for at prosessen rundt de ulike handlingene var avsluttet.

Mange av objektene som er lagt ned i de to røysene har en iboende dualitet. Hjorten krysser barrierene mellom innmark og utmark, skjellene lever i tidevannssonen mellom land og hav, malesteinene omformer kornet fra natur til kultur, og keramikken er et kulturelt produkt av naturelementene leire og kvarts. En lignende dualitet finner vi også i landskapet i bronsealder og førromersk jernalder. De to røysene ble anlagt i et jordbrukslandskap hvor menneskene bodde og hadde sitt daglige virke. Landskapet og forholdet mellom ulike landskapsrom var sannsynligvis svært viktig i de religiøse forestillingene i bronsealder. Noe forenklet kan en si at menneskene innrettet seg deretter ved a plasserer gravene på høyder, ofre i myrer og sjøer, og bosette seg mellom disse to sonene (Kristiansen, 1998; Kristiansen \& Larsson, 2005). Den mellomliggende sonen har imidlertid ikke vært noe enhetlig landskap. Her fantes det utmarks- og skogsområder, beiteland, åkrer og boplasser, og som tidligere nevnt ble denne sonen gjentatte ganger transformert gjennom rydding og ekspansjon i bosetningen. Disse aktivitetene kan ha satt balansen mellom menneskene og gudene i fare, og for å hindre kaos kan det ha vært nødvendig å utføre ritualer og ofringer i det transformerte landskapet (Meling, 2010). Ved å benytte objekter med en iboende dualitet, slik en har gjort på Sømme, forsøkte en å gjenopprette ubalansen som ble skapt ved omformingen og domestiseringen av landskapet. Siden dette var en kontinuerlig prosess, måtte ritualene stadig repeteres.

I midten av førromersk jernalder opphørte ritualene ved steinleggingene på Sømme, og de to anleggene ble forseglet og transformert til en sammenhengende røys. Vi vet ikke om dette skyldes et bevisst valg eller 
ikke. Den rituelle utøvelsen kan ha blitt overflødig, fått andre former, eller blitt flyttet til et annet sted. Det er imidlertid også mulig at de ble tvunget til å oppgi flaten på grunn av den omfattende sandflukten. Dateringene fra området tyder i hvert fall på at det gikk kort tid mellom forseglingen av steinleggingene 1a og $1 \mathrm{~b}$ og sandflukten. Uansett er det, «i etterpåklokskapens lys», noe ironisk å se at til tross for gjentatte ofringer for å skape balanse i tilværelsene, tok kaoskreftene overhånd på grunn av menneskenes omforming av landskapet.

\section{Avslutning}

De to røysene på Sømme er tolket som rituelle anlegg, bygget over tid i et jordbrukslandskap som var skapt gjennom omfattende nyrydning og bosetningsekspansjon. Både beliggenheten, funnmaterialet og konstruksjonsdetaljene kan relateres til ulike transformasjoner, og det er argumentert for at ritualene knyttet til røysene ble sett på som nødvendige for å opprettholde balansen i samfunnet da landskapet og bosetningen ble endret.

Røysene har mange fellestrekk med gravminner og ulike steinlegginger fra bronsealder og førromersk jernalder, og det er ikke usannsynlig at de hadde blitt tolket som graver dersom bevaringsforholdene for organisk materiale var langt dårligere. Likhetene mellom de to røysene og gravminner viser imidlertid at flere av symbolene og ideene som ligger bak utformingen av graver og gravfelt også ble benyttet $i$ andre situasjoner og sammenhenger. Mange av røysene fra bronsealder og førromersk jernalder uten gjenstandsfunn eller menneskelevninger har en kompleks oppbygning med ulike detaljer og byggefaser. Disse er som oftest tolket som graver, men røysene på Sømme åpner for at flere, særlig de som ikke ligger på gravfelt eller i nær relasjon til graver, kan være spor etter andre former for rituelle handlinger og praksiser i landskapet.

\section{Summary}

This article deals with two adjacent cairns dated to the Late Bronze and Pre-Roman Iron Ages, found at Sømme in Sola, Rogaland in Southwest Norway. Both cairns had been sealed by massive layers of turf and aeolian sand, creating very good preservation conditions. One of the cairns was a rather small and simple construction, containing two sherds of pottery and a piece of wood with chop marks. The other cairn was a more complex structure created over a period of at least 200 years. At the bottom, there was a stone slab platform at one side, and a small mound of clay and silt covered with stones at the other. In different parts of the cairn, a red deer antler, a piece of a red deer mandible, a collection of seashells, two grinding stones and a delicately crafted and $20 \mathrm{~cm}$ long wooden object of unknown function were found.
In the Late Bronze and Pre-Roman Iron Ages, this part of Southwest Norway was a highly developed and extensive agricultural landscape with numerous farms, fields and grazing areas. The landscape was the result of massive forest clearance and settlement expansion where former outfields were transformed into domestic landscapes. The author suggests that the two cairns were ritual constructions related to this transformation. The cairns are located in the transformed landscape, several of the objects (e.g. seashells, grinding stones, pottery) can be associated with transformation per se, and the multiple details in the construction of one of the cairns seem to reflect a narrative were the cairn itself is a subject of transformation. There is reason to believe that the rituals were seen as necessary for maintaining a balance in society during the rapid changes occurring to landscape and settlement.

\section{Sluttnoter}

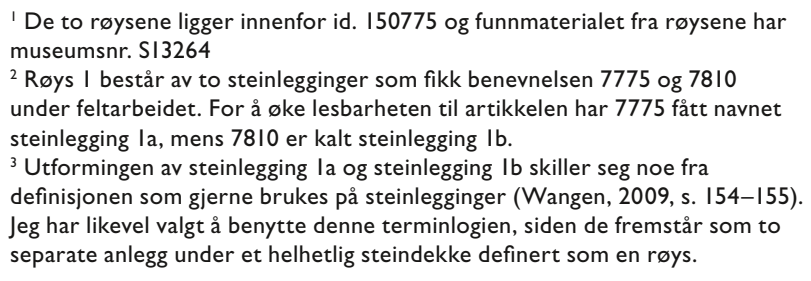

De to røysene ligger innenfor id. 150775 og funnmaterialet fra røysene har museumsnr. S13264

${ }^{2}$ Røys I består av to steinlegginger som fikk benevnelsen 7775 og 7810 under feltarbeidet. For å øke lesbarheten til artikkelen har $\mathbf{7 7 7 5}$ fått navnet steinlegging la, mens 7810 er kalt steinlegging $\mathrm{lb}$.

${ }^{3}$ Utformingen av steinlegging la og steinlegging lb skiller seg noe fra definisjonen som gjerne brukes på steinlegginger (Wangen, 2009, s. 154-155). Jeg har likevel valgt å benytte denne terminlogien, siden de fremstår som to separate anlegg under et helhetlig steindekke definert som en røys.

\section{Litteratur}

Aanderaa, F. (2015). Arkeologiske undersøkelser av bosetningsspor fra eldre jernalder på Einargården, Sande i Sola kommune. Frá haug og heiðni, nr. 2, 25-29.

Anfinsen, N. (2016). Snegler, skjell og fjæresand fragmenter av bronsealderens gravrituale? Årbok for Universitetsmuseet i Bergen 2016, 15-25.

Axelsson, C. (2005). Människor och djur. I C. Ask \& A. Berglund (Red.), Arkeologiska möten utmed väg 26: Borgunda - Skövde. Skrifter från Västergötlands museum 33 (s. 223-230). Skara.

Bertheussen, M. (2008). Arkeologisk utgraving på Søra Bråde 2. Revheim gnr. 39, bnr. 18, 26-1, 27 i Stavanger kommune. (Oppdragsrapport B 2008/17.) Arkeologisk museum i Stavanger.

Bjørlo, A. (2011). Et førromersk gårdsanlegg og vikingtidsgraver på Skadberg, Sola kommune. Frá haug og heiðni, nr. 3, 8-15.

Bjørn, A. (1927). Kvernstene i gravhauger. Maal og minne 1927, 38-43.

Bäck, M. \& Gansum, T. (2004). Keramikkskårenes historier om haugbyggeri. I M. Lönn (Red.), Aktuella Metodfrågor. Riksantikarieämbetet. Avdelning för arkeologiska undersökningar (s. 32-64). Stockholm.

Børsheim, R. L. (1999). Rydningsrøyser - en arkeologisk kildekategori. I L. Selsing, \& G. Lillehammer (Red.), Museumslandskap. Artikkelsamling til Kerstin Griffin på 60-årsdagen. Bind B. AmS-Rapport 12B (s. 347-354). Stavanger.

Carlie, A (2004). Forntida byggnadskult. Tradition och regionalitet $i$ södra Skandinavien. Riksantikvarieämbetet, Arkeologiska undersökingar, Skrifter No 57. Malmö.

Dahl, B. (2014). Arkeologisk utgraving av hus og graver. Myklebust gnr. 3, Sola kommune, Rogaland. 
(Oppdragsrapport B 2014/20.) Universitetet i Stavanger/ Arkeologisk museum.

Denham, S. D. (2016). Beinmaterialet frå Sømmevågen. Frá haug og heiðni, nr. 2, 13-17.

Dommasnes, L. H. (1997). Tradisjon og handling i førkristen vestnorsk gravskikk I. Undersøkelser på et gravfelt på Vereide $i$ Gloppen, Sogn og Fjordane. Arkeologiske Rapporter 21, Bergen Museum, Universitetet i Bergen. Bergen.

Dommasnes, L. H. (2001). Tradisjon og handling i førkristen vestnorsk gravskikk II. Fra Vereide til vikingtid. Arkeologiske avhandlinger og rapporter frå Universitetet i Bergen, Nr. 5. Bergen.

Eilertsen, K. S. (2013). Resultater fra kulturhistorisk registrering på Madla og Revheim i Stavanger kommune. Frá haug og heiðni, nr. 2, 13-18.

Eilertsen, K. S. (2016). Hus og hytter ved Tanangerveien. Frá haug og heiðni, nr. 1, 16-22.

Feldt, B. (2005). Synliga och osynliga gränser. Förändringar $i$ gravritualen under yngre bronsålder-förromersk järnålder i Södermanland. Stockholm Studies in Archaeology 37. Stockholm.

Fredriksen, P. D. (2005). Karet/kroppen/identiteten. UBAS Hovedfag/Master. Universitetet i Bergen Arkeologiske Skrifter 1 (s. 187-310). Bergen.

Fredriksen, P. D. (2006). Moving Closer to the Fire: Heat Transformations and Bucket-Shaped Pots in Burials. Norwegian Archaeological Review, Vol. 39, No. 2, 126-137.

Fyllingen, H. (2015). Resultater fra undersøkelsene av et gravfelt, en flyttblokk og bosetningsspor på Tjora gnr. 10, Sola kommune, Rogaland. AM-Profil 2. Stavanger.

Gansum, T. (2002). Fra jord til handling. I K. Jennbert, A. Andrèn \& C. Raudvere (Red.), Vägar till Midgård 2. Plats och praxis. Studier av nordisk förkristen ritual (s. 249-286). Nordic Academic Press. Lund.

Grønnesby, G. (2009). En reise gjennom liv og død, ild og vann. En bronsealders gravruin i Steinkjær. I G. Grønnesby \& M. M. Henriksen (Red.), Det 10. nordiske bronsealdersymposium. Trondheim 5.-8. okt. 2006. VITARK 6 (s. 66-78). Trondheim.

Herschend, F. (2009). The Early Iron Age in South Scandinavia. Social Order in Settlement and Landscape. Occasional Papers in Archaeology 46. Uppsala.

Hinsch, E. (1953) Förromersk jernålder i Norge. Finska Fornminnesföreningens Tidskrift LII, 51-71.

Holmberg, C. L. (1998). Prehistoric Grinding Tools as Metaphorical Traces of the Past. Current Swedish Archaeology Vol. 6, 1998, 123-142.

Kaliff, A. (1992). Brandgravskick och föreställningsvärld. En religionsarkeologisk discussion. Occasional Papers in Archaeology 4. Uppsala.

Kaliff, A. (1997). Grav och kultplats. Eskatologiska föreställningar under yngre bronsålder och äldre järnålder $i$ Östergötland. Aun 24. Uppsala.

Kaliff, A. (1998). Grave structures and alters: Archaeological traces of Bronze Age eschatological conceptions. European Journal of Archaeology Vol. 1(2), 177-198.

Kaliff, A. (2004). Offerritual och gravplatser - några kommentarer kring sambandet mellan arkeologisk terminologi och tolkning. I L. Melheim, L. Hedeager \& K. Oma (Red.), Mellom himmel og jord. Foredrag frå et seminar om religionsarkeologi. Isegran 31. januar-2. februar 2002. OAS, vol. 2 (s. 274-290). Oslo.
Kristiansen, K. (1998). The Construction of a Bronze Age Landscape. Cosmology, Economy and Social Organisation in Thy, Northwestern Jutland. I B. Hänsel (Red.), Mensch und Umwelt in der Bronzezeit Europas (s. 281-291). Kiel: Oekter-Voges Verlag.

Kristiansen, K. \& Larsson, T. B. (2005). The Rise of Bronze Age Society. Travels, Transmissions and Transformations. Cambridge: Cambridge University Press.

Lillehammer, A. (1976). En keltertidsgrav frå det sentrale Jæren. Stavanger Museums Årbok 1975, 35-51.

Lund, H. E. (1934). Graver og gravskikk i en bronsealders haug på Jæren. Stavanger Museums Aarshefte 1932-33, 57-69.

Lund, H. E. (1939). Et eldre jernalders gravfunn med to klebersteinskar fra Årsland i Varhaug. Klebersteinkarenes eldste historie. Stavanger Museums Årshefte 1937-38, 41-56.

Melheim, L. (2006). Gjennom ild og vann. Graver og depoter som kilde til kosmologi i bronsealderen i Øst-Norge. I C. Prescott (Red.), Myter og religion i bronsealderen. Studier med utgangspunkt $i$ helleristninger, graver og depoter $i$ SørNorge og Bohuslän. OAS vol. 5 (s. 13-194). Oslo: Unipub.

Melheim, L. (2016). Recycling Ideas: Bronze Age Metal Production in Southern Norway. BAR International Series 2715. Oxford: BAR Publishing.

Meling, T. (2010). Et keramikkfunn fra slutten av yngre bronsealder ved Tornesvatnet i Haugesund - en offernedleggelse i gårdsnær utmark? Primitive tider 12, 93-101.

Meling, T. (2016). Skjult av fleire meter med tjukke torv- og sandlag. Unike steinalderbuplassar frå Sømmevågen i Sola kommune. Frá haug og heiðni, nr. 2, 3-5.

Meling, T. (2017). Hus fra bronsealder og førromersk jernalder på Sømme i Sola. Frá haug og heiðni, nr. 2, 20-24.

Munkenberg, B. A. (2010). Det mångefacetterade sakrala landskapet. I H. Petersson \& C. Toreld (Red.), Utblickar från Munkedal. 10000 år av bohuslänsk förhistoria. Kulturhistoriska dokumentationer 27 (s. 256-279). Uddevalla: Bohusläns museums förlag.

Myhre, B. (1971). Steinringer frå førromersk jernalder. Arkeo, nr. 1, 10-12.

Myhre, B. (1981). Sola og Madla i førhistorisk tid. AmSSmåtrykk 10. Stavanger.

Myhre, L. N. (2004). Trialectic archaeology. Monuments and space in Southwest Norway 1700-500 BC. AmS-Skrifter 18. Stavanger.

Nybruget, P. O. \& Martens, J. (1997). The Pre-Roman Iron Age in Norway. I J. Martens (Red.), Chronological problems of the Pre-Roman Iron Age in Northern Europe. Arkæologiske Skrifter 7 (s. 73-90). Copenhagen: Danish University Press.

Pilø, L. (1989). Den førromerske jernalder $i$ Vest-Norge. Et kulturhistorisk tolkningsforsøk. Hovedfagsoppgave, Universitetet i Bergen. Bergen.

Prøsch-Danielsen, L. (1993). Prehistoric agriculture revealed by pollen analysis, plough-marks and sediment studies at Sola, south-western Norway. Vegetation History and Archaeobotany (1993) 2, 233-244.

Prøsch-Danielsen, L. \& Selsing, L. (2009). Aeolian activity during the last 9200 calendar years BP along the southwestern coastal rim of Norway. AmS-Skrifter 21. Stavanger.

Prøsch-Danielsen, L. \& Simonsen, A. (2000). The deforestation patterns and the establishment of the coastal heathland of southwestern Norway. AmS-Skrifter 15. Stavanger. 
Rosvold, J., Andersen, R., Linnell J. D. C. \& Hufthammer, A. K. (2013). Cervids in a dynamic northern landscape: Holocene changes in the relative abundance of moos and red deer at the limits of their distributions. The Holocene 23(8), $1143-1150$.

Rødsrud, C. (2004). Gravfelt fra førromersk jernalder og overgangen til romertid. I L. Melheim, L. Hedeager \& K. Oma (Red.), Mellom himmel og jord. Foredrag fra et seminar om religionsarkeologi. Isegran 31. januar-2. februar 2002. OAS, vol. 2 (s. 274-290). Oslo.

Rødsrud, C. L. (2008). Kontinuitet i en brytningstid? Samfunnsutviklingen under førromersk jernalder. I K. Chilidis, J. Lund \& C. Prescott (Red.), Facets of Archaeology. Essays in Honour of Lotte Hedeager on her $60^{\text {th }}$ Birthday. OAS, vol. 10 (s. 397-408). Oslo: Unipub.

Rødsrud, C. L. (2012). I Liv og Død: Keramikkens sosiale kronologi i eldre jernalder. Doktogradsavhandling, Kulturhistorisk museum, Universitetet i Oslo. Oslo.

Selsing, L. \& Mejdahl, V. (1994). Aeolian stratigraphy and thermoluminescence dating of sediments of late Holocene age from Sola, southwest Norway. Boreas, Vol. 23, 92-104.

Stålbom, U. (1997). Waste or What? Rubbish Pits or Ceremonial Deposits at the Pryssgården site in the Late Bronze Age. Lund Archaeological Review 1997, 21-35.

Svanberg, F. (2000). Gravar i röjningsröseområden. De förmodade gravarna inom Hemneda RAÄ 77 och problematiken kring röjningsröseområden och gravar i södra Sverige. I P. Lagerås (Red.), Arkeologi och paleoekologi i sydvästra Småland. Tio artiklar från Hamneprojektet. Riksantikvarieämbetet. Arkeologiska undersökingar Skrifter No 34 (s. 113-133). Malmö.

Tansøy, B. (2001). To hus og ein heil haug med keramikk Nokre resultat etter utgravinga på Utsola sommaren 2001. Frà haug og heiðni, nr. 4, 32-34.

Vretemark, M. (2013). Late Bronze Age hunting in Middle Sweden - Evidence from «King Björn`s mound» in Håga and the surrounding settlement. I O. Grimm \& U. Schmölcke (Red.), Hunting in northern Europe until 1500 $A D$. Old traditions and regional developments, continental sources and continental influences (s. 207-214). Wachholtz.

Wangen, V. (1998). Gravfeltet på Gunnarstorp. Et monument over dødsriter og kultutøvelse i 1200 år. I E. Østmo (Red.), Fra Østfolds oldtid. Foredrag ved 25-årsjubileet for Universitetets arkeologiske stasjon Isegran. Universitetets Oldsaksamlings Skrifter. Ny rekke, Nr. 21 (s. 153-171). Oslo.

Wangen, V. (2009). Gravfeltet på Gunnarstorp i Sarpsborg, Østfold. Et monument over dødsriter og kultutøvelse i yngre bronsealder og eldste jernalder. Norske Oldfunn XXVII. Oslo. 